\title{
Reality of Politic and Democracy Regional Autonomy Era in the Southeast Sulawesi of Indonesia
}

\author{
Muhammad Zein Abdullah ${ }^{1}$, Weka Widayati ${ }^{2}$, Bahtiar $^{3}$, Dasmin Sidu $^{4}$ \\ ${ }^{1,3}$ Faculty of Social and Political Sciences, Halu Oleo University, Indonesia \\ ${ }^{2}$ Faculty of Sciences and Earth Technology, Halu Oleo University, Indonesia \\ ${ }^{4}$ Faculty of Agriculture, Halu Oleo University, Indonesia
}

\begin{abstract}
The practice of democracy in the Southeast Sulawesi generally hadn't run as expected. The broad authority to develop in a local democracy had not been realized properly. The practice of democracy through the establishment of political parties, general elections, elections of leaders in the region (regional heads such as governors, mayors and regents along with his deputy, including the head of the village), the implementation of public policy, was not capable of running as its ideal concept. Even the organizers of the government and local authorities had not been able to fully follow the rules and regulations of applicable laws that underlie the implementation of democratic values in Indonesia such as the application of the principles of good governance that had been mandated by various laws of local government management. The participatory development planning ran only as symbolic, normative and virtual, the local budget management was still at the discretion of the authorities, the aspirations and needs of the people were still lacking to realize. It illustrated the lack of substantive participation of the public, the responsiveness of government officials was still low, the concern of the government to the local people in managing resources and budgets were still lacking, the capitalization of power still continued.
\end{abstract}

Keywords: Reality Local Politic, Regional Autonomy

\section{Introduction}

Indonesia had been a democratic country since the authoritarian rule of New Order undermined by the student movement in 1998. The student movement of 1998 that demanded a fundamental change in the administration of state and government are: from a centralized, authoritarian and repressive approach to a decentralized, autonomous and democratic approach. Conceptually, efforts to achieve democratic governance both at national and region level had become a national provision by all elements and components of the ruler in this country. That, at least, could be observed through several indicators, among others:

First, of all there was greater freedom for each element and community members to form organizations, including establishing a Political Party as an institution which was expected to establish to the maximum representation of citizens in the political processes and governance in state administration. The presence of Political Parties which was expected to expand the preference for citizens to channel their political aspirations as part of human rights as citizens of a nation, and at the same time could increase the political participation of every citizen; Secondly, there were fundamental changes through a constitutional amendment (UUD 1945) and various Laws regarding the selection of leaders at every change of leadership in the organization of the state, both at central level (the president and vicepresident) and regional level (the regional head and deputy).

If previously the president and vice president were elected by the MPR members, and local leaders were elected by DPRD members who were members of the people's representatives (representative democracy), since 2004, the election of the president and vice president as well as the regional head and deputy carried out directly by the people (direct democracy) with the hope that the chosen leader who was the best man who's really the people's choice directly. They were chosen because of their competence, achievement, reputation, ability, leadership, and a number of other advantages they had, through a process that was good and right according to the rules, not by engineered procedures, manipulation of the process or money politics or obtained by any ways so the leader was not a leader that all of the people hoped.

Thirdly, the wider space for citizens to be directly involved in the political processes and the implementation of policies both at national and regional level through the involvement of the public in participating in the discussion of various Laws and regional regulations related to the public interest. It was intended that any policy that was born was able to answer the problems of the people, it became easy to implement, and deliver maximum results in addressing various issues related to the Laws and regulations. For example, before a draft (RUU) was discussed in a plenary forum in DPR or before the draft of local Regulations (Raperda) was discussed in the plenary forum by DPRD to be set, it must first be consulted to the public. Public consultation on a draft law or regulation carried out as part of efforts to absorb the aspirations of the citizens related to the Law or the regulations, particularly Laws or regulations directly involving with the people's interests. This was a manifestation of the efforts to realize the implementation of the process of democratization in the country, especially in the process of public policy;

\section{Volume 4 Issue 12, Desember 2015}




\section{International Journal of Science and Research (IJSR) \\ ISSN (Online): 2319-7064}

Index Copernicus Value (2013): 6.14 | Impact Factor (2014): 5.611

Fourthly, there was the obligation of the government (central and local) especially planning apparatus and development actors to involve the public directly in the planning process and development programs substantively, not participation formally. It was marked by the birth of Law No. 25 of 2004 on National Development Planning System. In this Law clearly stated there was obligation to involve the local community in the planning process of the development program through planning approach from the bottom (bottom-up planning). It was intended that each program determined by using state budget / regions was able to provide to overcome the problems of the people, give useful results and impact for the improvement of quality of life of local people; characteristics of democracy were in fact seen from the participation of citizens directly in the process of determining program and activities of their own to overcome the problems they faced, with an assumption that they knew the root of the problem, so the solution to overcome the problems must be given to the local people, and the government only as mediation, facilitation, direct, and provide regulation, setting up resources, and budgets as well as appropriate work methods to achieve the desired objectives.

Fifthly, there were the provision and advice, express or implied in the various rules concerning about good governance in the process of public administration and development, including in terms of resource management and budget of the country / region, as mandated in Law No. 17 of 1999 on regional financial and Law No. 33 on Financial Balance of Center and Region. This work was done by requiring to each element of countries, including heads of state and their apparatus, heads of regions and their aides, including the bureaucrats to continue applying the principles and values that characterized the good governance, such as the existence of a share vision, participation, transparency, accountability, responsibility, responsiveness, affectivities, efficiency, adherence with the law (rule of law), equity, and alignments to the poor (pro-poor).

The five aspects were an overview of the efforts to realize the ideal of democracy in the post-reform in Indonesia. In the local context, efforts to realize democracy that were more clearly, well and properly were more open and prospective in line with decentralization and greater autonomy had been implemented since the enactment of laws on regional autonomy that was Law No. 22 of 1999 on local government's revised Law Number 32 of 2004 by inserting clauses direct local elections, as well as Act 25 of 1999 on the central and local financial balance amended by Law No. $33 / 2004$ on the same thing, with emphasis on the good and right development of local budgets governance.

With the two Laws accompanied by various other regulations, the area had the authority to regulate, administer, and run the administration, development and public service autonomously guided by the principles of substantive democracy in order to accelerate the realization of the people's welfare in the area. Unfortunately, the practice of democracy as the ideal cannot be realized in Indonesia today and the hope that democracy can improve overall welfare of the people in the area had not realized maximally, including in the Southeast Sulawesi. The question was how far has the values of the ideal democracy to be realized as well in the administration of local government in Southeast Sulawesi? If not maximized embodiment, what was the causes of not applying democratic values in totality? What were the prospects of democracy in the autonomous regional government in Southeast Sulawesi?

\section{Literature Review}

Democracy was a system in which the people govern themselves and were often called the government of the people, by the people and for the people. According to Dahl, democracy was also marked by the implementation of the general election in which every citizen entitled to vote and to be voted, there were equal rights in politics, political parties competed for popular support, recognition of the rights and freedom of speech, assembly, association, determining the choice and freedom of the press, including participating in the implementation of public policies, especially when the people's representatives in the government no longer voiced the interests of society. To be free, according to Hegel in Gidens, society should be autonomous, not forced by extreme force beyond rational mastery. Freedom was not selfishness, but the rational freedom used creative abilities of themselves as members of a civilized society.

A country that adopted democracy always made democratic values as the first principle of the state administration, especially in terms of governance, development and public service, including in matters of public policy implementation. Gould explained that recent democratic developments had relevance to the theory of human rights, political rights and social rights. If at first, the theory of human rights only emphasized the political and civil rights. Furthermore, rights were expanded again in the rights associated with ownership of economic, social rights, cultural rights and the right to enjoy development. Recognition of the equal rights and equality of social, economic and cultural development, were complementary and required as a basic theory and ethics of modern democratic government. Hobbes, Locke and Rousseau and Gould explained that, human rights including freedom and freedom of speech were a natural law, if it was violated by one party or group; it will give birth to disputes or warring among one another.

In the public policy arena, according to Dahl (2001), the policy could be said to be done democratically if: (1) there was the involvement of citizens; (2) stakeholders were represented to the fullest; (3) there were equal rights for every citizen in the decision-making process; (4) information regarding the policy was easily accessible well and evenly so that each element of the public can obtain and understand it; (5) the public supervised the implementation of the policy. Recognition of citizen involvement in the organization of the state was one manifestation of the implementation of the political rights of the people. Things like that will have implications for efforts to encourage the fulfillment of basic rights, social rights, and the right to develop a culture. In harmony with it, Mahmassani (1979) described that the essence of democracy was to make people as a source of

\section{Volume 4 Issue 12, Desember 2015}




\section{International Journal of Science and Research (IJSR) \\ ISSN (Online): 2319-7064}

Index Copernicus Value (2013): 6.14 | Impact Factor (2014): 5.611

legitimacy. Participation in governance including human rights, together with the right to vote and to be voted, the right positions and control the government. While the civil rights included the right to live, the right to have education, own property, earns a living, expressing ideas, religious freedom, and the right to have children.

The citizen participation in decision making was defined as the best possible way. Schumpeter (1942) and Sorensen (1993) as quoted Effendi (2003), the process of democratization was marked by political institutional arrangement, the individual had an autonomous power, and no fair competition was done to gain support. Everyone was free to determine their lives, acquired the rights and obligations consistently, within the framework of the implementation of a balanced political role. According to Stoker (2002) many ways allowed the public to participate in the political process, the implementation of policies and the implementation of development programs at the local level without being tied to formal representative democratic tradition. Political parties cannot be granted exclusive rights as the driving time and bearers aspirations because they were not always in favor of the people.

Development of democratic policy had been linked to the practice of governance that was controlled by the owners of power. Because of it, the commitment of policymakers to implement a policy implementation democratically determined the quality of public participation, besides, related to the capacity of the citizens themselves. In view of Wilcox, it was related to public access to information policies, transparency, and accountability of government aligned with the concept of good governance

The involvement of stakeholders was a prerequisite for democracy and their approaches were often based on shared interests of each individual. The underlying fastener elements, among others: (1) The existence of subsistence equal rights as citizens; (2) The similarity of ideology because of the teaching of religion, the same ideology that recognized its existence; (3) The similarity of the structural position of the residence status due to inhabiting the same territory administratively; (4) Common vision and political mission, as a member of the same political party; (5) The similarity in social structure as an ethnic group that had customs, language and culture of the same area; (6) the functional similarity bound by professional status, which implies the similarity of work, such as membership in the association, and so on; (6) The similarity of socio-economic status were misclassified based on the real conditions of life in carrying out activities such as poor-rich, education that can be identified to be the elite, the middle, most of community groups, grassroots.

Equal rights in decision making. In a democratic system, the indicator indicating that a policy had been implemented democratically was seen from how far the decision was made depicting the representation of the aspirations of stakeholders. The representation of stakeholders, in addition to ensuring that all interest groups were represented in the decision making process, the generated decision can describe the aspirations of all parties. Thus, in its implementation, the resistance of the various parties concerned with the referred policy can be minimized.

The presence of people was often problematic when meeting forums related to formal affairs. Whereas the recognition of the rights of citizens in decision-making as illustrated by Dahl can generate benefits, among others: (1) the forum produced a legitimate decision, because people had a stake in policy-making process; (2) the implementation of decisions was more or less getting resistance from the public; (3) producing a more balanced decision to accommodate the interests of stakeholders; and (4) the owner was not an arbitrary power to make decisions. According Kleden, the involvement of citizens can encourage reduced misuse of funds, encouraging the effectiveness, efficiency, transparency, accountability, and encourage the allocation of resources, as well as pro-people budget.

Dissemination of information to the public was one manifestation of transparent and accountable democracy from the organizers and was expected to ensure the creation of community service. According to Dahl (2001) and Smith (1985), Bentham (1996), Manor (1998), Gaventa and Valderama, that the local autonomous government had the potential to realize the ideal of democracy as long as the implementation of information was accessible to the public and local government was responsive to the people's problems. Democracy and decentralization were more meaningful if the implementation of government policy information was accessible to the public.

According to Smith, autonomy entitlements could realize government responsiveness to the demands of society, besides encouraging political equality and accountability policies organizer. Responsiveness to local problems would be quickly realized if the government had an autonomous right to manage his administration. Piere and Peter explained that it was important to give the right of autonomy to the regions so that the central government could focus on strategic issues, long-term, international-domestic network, and coordinated based on global issues, national and sub national. Local governments configured role of the state on the issue of the appropriate environmental conditions and local issues. Responsiveness to community problems could be realized, if the local government had the authority to make and administer policy.

Mohanty (1999) autonomy in a democratic government aimed to introduce democratic values to the community or society at large scale, improve the administration of the government to be more responsive to local issues, create efficiency and effectiveness in public services at the local level. Autonomy according to Osborne and Gaebler, making organization close to the service could be more flexible in addressing the problems of citizens or meet customers' needs changing faster and more effective, because the personnel front lines knew more about the events that occurred at any time and be able to create the best solution, as long as supported by a participatory organization, the accurate and fast information, the innovative and creative apparatus. Advantages of decentralization for countries building democracy according to Disk, is expanding the power of the people and their representatives in parliament, equitable

\section{Volume 4 Issue 12, Desember 2015}




\section{International Journal of Science and Research (IJSR) \\ ISSN (Online): 2319-7064}

Index Copernicus Value (2013): 6.14 | Impact Factor (2014): 5.611

social activities, economy and culture through the delegation of responsibility or management planning and management at lower levels of government, and close to the people.

In the local context, efforts to realize the ideal democracy was really possible because of local government administration as an entity given the authority and had the rights of autonomy for creative embodiment of practice in a democratic policy in organizing governance, development and public service. In this context, the local government could bring about equality for every citizen's political role in the processes of local governance in the region. In the view of Smith (1981), governance and local democratic policies were often characterized by the implementation of the political role of the equality of citizens and stakeholders, the accountability of the organizers of public policy, the implementation of local policies that were responsive to various problems that developed at the local level. This concept could be realized in every aspect of the regional administration, especially which directly involved local residents.

Implementation of regional autonomy democratically gave opportunities for the local government's direct relationship with its citizens, on condition that, traffic information was not clogged and no alienation of state for information concerning the interests of society or its citizens. Such patterns enable local policy providers to obtain more information and specific understanding about the condition and needs of the local community, flexibility in the control and allocation of resources. The focus would be more emphasis on meeting the needs of local priorities and community participation was assured fullest. The Implementation of the policy and decision-making could be done effectively and efficiently in response to the problems faced by citizens. The local government might provide more opportunities for citizens to participate in public affairs of government, as well as allowing an increase in the participation of citizens, who previously less concerned and alienated from the government, and also made citizens become aware and active in local governance.

\section{Methodology}

The paper begins by describing work contexts integral with the reality of the practice of democracy could transition: regulation, good governance and accountability; new work structures; and knowledge development. The discussion then examines transitions research in practice of democracy, developmental psychology, life course sociology, and implementation of public policy. These perspectives are compared critically in terms of questions and approaches, contributions to understanding practice of democracy transitions, organize the administration, development and democratic public service and limitations. The contradiction was not only at the level of concepts but it directed at the level of empiricism which has implications for conflict between community groups whose inclinations are not be able to mediated by local government.
The practice of democracy in the Southeast Sulawesi generally had not run as expected. The broad authority to develop in a local democracy had not been realized properly. The practice of democracy through the establishment of political parties, general elections, elections of leaders in the region (regional heads such as governors, mayors and regents along with his deputy, including the head of the village), the implementation of public policy, was not capable of running as its ideal concept. The subject is the whole object or phenomenon to be done or done in a paper. Kriyantono (2008) says subject is a generalization region consisting objects that have a certain quantity and characteristics. In generally, information collection in this paper is done by using the technique of observation, in-depth interviews, Focus Group Discussion (FGD) and documentation. In-depth interviews will be carried out on key informants primarily. In keeping with the focus and purpose of research to uncover reality of the practice of democracy in the Southeast Sulawesi. Data analysis was using a model description presents and analysis of information using a model interactive (Silalahi, 2009).

\section{Results and Discussion}

Broad autonomy became opportunities for the region to organize the administration, development and democratic public service, in accordance with the principles of substantive democracy not only to meet the procedural requirements. In the case of Southeast Sulawesi, the reality of the practice of democracy could at least be seen as follows: Firstly, the establishment of political parties continued growing, marked by the declaration of a new political party such as the party of National Democrats (Nasdem) and the various political parties that did not meet the requirements of votes undergo reform in order to follow the elections in 2014; Political parties had not shown a fundamental and substantive changes, they still adhered to the concept of the party as an institution that had the power, they had not become institutions that carried the aspirations of the people. One case, in the process of nominating candidates for regional heads, political parties in this area still adhered to the paradigm of preparing a vehicle prospective regional heads who wanted to fight in local elections directly; they had not shifted to paradigm looking figure who deserved to be a regional leader.

Both paradigms that had fundamental differences. If the paradigm was to prepare the vehicle for the candidates of head region, the consequences: (1) political parties only wanted to propose candidates of regional head if his political party was paid or hired by the candidates of head region; (2) there were no consequences, in which political parties must strive to win the nominee; (3) election of the proposed candidates depended on the size of the charge given to the political party; (4) becoming the source and the beginning of corruption in local government because the winning candidate in the elections already were in a trap of capitalization power in the region.

It was different from the paradigm of searching for a decent figure who had the capabilities to become a leader in the 


\section{International Journal of Science and Research (IJSR) \\ ISSN (Online): 2319-7064}

Index Copernicus Value (2013): 6.14 | Impact Factor (2014): 5.611

area. If the latter was used, then the logical consequences Wet: (1) political parties really selected candidates of region head by using a rational and professional criteria, such as competence, ability, reputation, leadership, support base and morality; (2) there were struggling values built by political parties for the winning candidate as they were responsible for nominating candidates for regional head; (3) the candidate determination was not based on the amount of money paid to political parties, but rather the ability of candidates to win the battle with the balance of the mass support base, popularity, achievements of the past, a vision, a mission and a clear program for the people; (4) corruption in the government at least could be avoided, because the elected regional heads didn't spend much cost. These conditions would benefit the people, because the head of the region was not burdened by the cost of politics in the election issuance.

Secondly, the practice of democracy in the organization of local elections was still problematic both at the level of the organizers, candidates and voters in the community. Almost all cases of direct regional elections (election regent, mayor and governor) were problematic. It was characterized by rampant lawsuit party who felt aggrieved over the implementation of local democratic party which was direct local elections that had been held in all the district / city and district result of regional expansion, since the performance of the Election Commission was not optimal to show their professionalism, cheating candidates, money politics, and others; Thirdly, the practice of policy implementation especially in the discussion of the draft of local regulations (Raperda) had not been conducted openly through public consultation. The Caring of people to participate in the process of policy implementation was still low, and there was still reluctance of society to demand political rights to participate in the implementation of policies in the area. People still strong paternalistic ideology, in which the public generally believed what the government (head of the region along with his team, as well as the Parliament), had been considered something right. Critical power levels of society were still lacking, and social control in the process of implementation of policies and budgets had not been going well. The condition was used by local authorities to manage resources and budgets according to its own version for the benefit of individuals or groups. (Case of the mining management in Bombana district, Kolaka, North Konawe and teak forests in Muna Island).

Finally, democratic values such as the recognition of political rights of citizens merely through general elections and the election of region head and village head, yet at the level of implementation of development policies. It was still much colored by the deviant practices of buying and selling voice (money politics), rather than through a rational selection process according to the common sense of the community. Participation in the implementation of development policies was still like the old one, it was still apparent, formality, and even manipulation of participation; Access to information and policy-budgeting problem was not maximized, due to the persistence of the closure of local governments to manage budget resources in the area. Budget information monopoly phenomenon still occurred, accountability was not going well, inequality implementing rules regarding good governance budgets such as efficiency, effectiveness, pro poor, not maximally realized. In short the application of the principles of good governance in the administration of the state implementation cannot be realized well

The practice of democracy in the Southeast Sulawesi generally hadn't run as expected. The broad authority to develop in a local democracy had not been realized properly. The practice of democracy through the establishment of political parties, general elections, elections of leaders in the region (regional heads such as governors, mayors and regents along with his deputy, including the head of the village), the implementation of public policy, was not capable of running as its ideal concept. Even the organizers of the government and local authorities had not been able to fully follow the rules and regulations of applicable laws that underlie the implementation of democratic values in Indonesia such as the application of the principles of good governance that had been mandated by various laws of local government management. The participatory development planning ran only as symbolic, normative and virtual, the local budget management was still at the discretion of the authorities, the aspirations and needs of the people were still lacking to realize. It illustrated the lack of substantive participation of the public, the responsiveness of government officials was still low, the concern of the government to the local people in managing resources and budgets were still lacking, the capitalization of power still continued. It may be caused by:

Firstly, the public understandings of the democratic values were still low. Generally, the public and especially the local officials only knew the term democracy but did not yet have a deep understanding of the meaning and values of real democracy. Most people in the region understood democracy only at the level of use of the right to vote and to be voted in the electoral process. Implementation of policies democratic as illustrated Dahl had not been understood moreover implemented. If applied as it had been mandated by the Law, its implementation was translated to his version to make profits for themselves and the group. Therefore, a substantive democratic learning to the wider community should be developed. Secondly, the awareness of public officials was low. Awareness of officials as people who had to think about the interests of the wider community increasingly eroded by the existence of political competition through misinterpretation democracy. Democracy became into divisions apparatus, support and forget its role as a public servant should not be stuck in the game and fight of political power at the local level. Here, there was a dilemma for the apparatus in the area, because of the politicization of the bureaucracy by political players in the region.

The bureaucratic apparatus were faced with two choices to support or not support the direct election battle. It was wrong if they support one of the candidates because they were not neutral as the bureaucrats who should be neutral, but if they didn't support, they were judged not to be contributed so they do not get their share of power in the area after the election process is completed. For this case, the concept of ensuring the neutrality of bureaucracy in local power struggles must be reviewed by more strategic regulations of civil service and local officials. Thirdly, the political cost in the process of

\section{Volume 4 Issue 12, Desember 2015}




\section{International Journal of Science and Research (IJSR) \\ ISSN (Online): 2319-7064}

Index Copernicus Value (2013): 6.14 | Impact Factor (2014): 5.611

regional head recruitment was very expensive. Political cost in regional head elections increased because the errors to put paradigm of the election of regional head by the authorities in political parties. The implication was, the candidates who could win were those who had spent most. As a result, when he was in peak power in being the regional head, which was considered, was how to restore the political costs that had been issued. It was needed to develop a system of recruitment of political leaders at the lowest cost in order to give a quality leader in the region.

Fourthly, human opportunistic character in the implementation of the law was still low and the rules themselves did not provide a deterrent effect. Every human being was opportunistic and greedy. Only rules that limited the greed and arbitrariness of human (Thomas Hobs). In an era of democracy, democratic governance process cannot be effective if it was not accompanied by any rules of a binding, strong, proper legislation that made the deterrent effect and done consistently by all the elements. The state would be weak if the law was weak, or countries would also be weak if the law was strong but not implemented consistently. To ensure implementation of the law went well, wide supervision was required by all elements in society as suggested by Dahl (2001). Broad oversight included formal supervision by the judiciary, the political supervision by the legislature, the inherent supervision and administration by the leadership of the bureaucracy, social supervision by the community and self-monitoring by every actor in the regional administration.

\section{Conclusion}

The autonomous local governments had not been able to realize the implementation of ideal democracy with its values such as substantive citizen participation, involvement of stakeholders to the maximum, equal rights in public decisionmaking, information dissemination and surveillance of citizens had not gone well. The democracy just ran formalistic in certain activities such as the legislative elections and direct elections of regional heads which was still colored by the deviant practices such as money politics and corruption in the implementation by the organizers.

The implementation of democracy were low because the understanding of the general public towards democratic values was still low, the awareness of public officials was low, the cost of politics in the process of regional leader recruitment was very expensive, the human opportunistic character itself amid the implementation of the law was low and the rules themselves did not provide a deterrent effect and supervision had not gone well.

Substantive democracy learning to the general public needed to be developed, it was necessary to rearrange personals and local officials more strategically so as not to get stuck in the environment of power locally, The system of regional leader recruitment with the lowest political cost needed to be developed to provide a quality leader in the region, and needed the strong rule of law giving deterrent effect and implemented consistently with supervision in the implementation.

\section{References}

[1] Asyumaidi Azra, MA. (2005). Human Rights Democracy and Civil Society, Prenada Media. Jakarta.

[2] Azfar, Omar, Satu Kähkönen, Anthony Lanyi, Patrick Meagher, and Diana Rutherford, (1999), Decentralization, Governance and Public Services, The Impact Of Institutional Arrangements: A Review of the Literature, IRIS Center, University of Maryland, College Park.

[3] Bardhan, Pranab, (2002). Decentralization of Governance and Development, Journal of Economic Perspectives - Volume 16, Number 4-Fall.

[4] Basuki, Tobias, (2006), Decentralization in Indonesia and China: An Answer Crisis Paper presented at the annual meeting of the Midwest Political Science Association, Palmer House.

[5] Brilantes Jr., Alex, (2004), Decentralization Imperatives, Lessons from Some Asian Countries, Journal of International Cooperation Studies, Vo.

[6] Brinkerhoff, Derick (2006), Decentralization and Community Empowerment: Does community empowerment deepen democracy and improve service delivery? USAID of Democracy and Governance.

[7] Cheema, G. Shabbir and Dennis A. Rondinelli, (1983), Decentralization and Development: Policy Implementation in Developing Countries, Beverly Hills, Sage, and California.

[8] Cheema, G. Shabbir and Dennis A. Rondinelli, (2007), Decentralizing Governance: Emerging Concepts and Practices, Brookings Institution Press.

[9] Gaebler Ted, Osborne, David, (1996). Reinventing Government, Enterprise bureaucracy; Entrepreneurial Spirit Transforms into Public Sector. PPM-Jakarta.

[10]Hoessein, Bhenyamin, (1995) Decentralization and Regional Autonomy in the Republic of Indonesia: Are the wheels decentralization will shift from efficiency to democracy? (Indonesian version) Jakarta: FISIP-UI, 18 November.

[11] Rondinelli, Dennis, (1999), "What is Decentralization?", in World Bank, Decentralization Briefing Notes, WBI Working Papers

[12]Ryan, Jeffrey J., (2004), Decentralization and Democratic Instability: The Case of Costa Rica", Public Administration Review.

[13] Silalahi, Ulber (2009), Social Research Methods, Refika Aditama, Bandung

[14] Smith, Brian C., (1985), Decentralization: The Territorial Dimension of the State, London: Unpim.

[15] Turner, Mark and Hulme David, (1997), Governance, Administration and Development: Making the State Work.

[16] World Bank. (2000), Helping Countries to Combat Corruption: Progress at the World Bank since 1997. Washington DC Washington DC

[17] World Bank, (1999), Beyond the Center: Decentralizing the State, Washington DC 